\title{
Er diabetesepidemien i ferd med å snu?
}

\section{Data fra USA tyder på en dobling i forekomst og insidens av diabetes i perioden 1980-2012, men at utvik- lingen de siste årene kan ha snudd.}

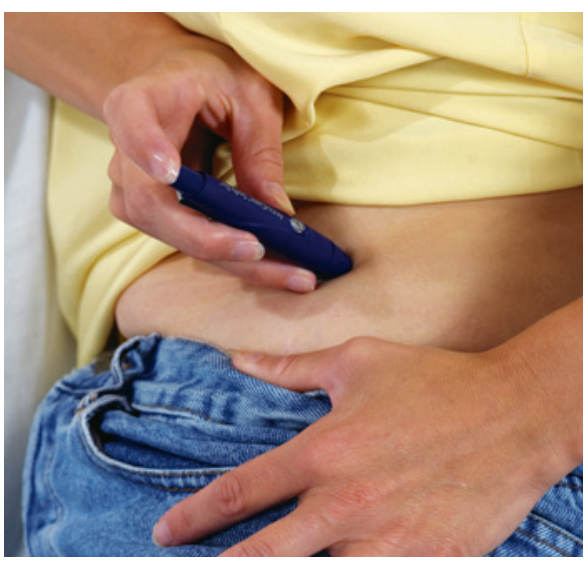

Illustrasjonsfoto: Sciencephoto/NTB scanpix
I perioden 1980-2012 deltok rundt 650000 amerikanere i alderen 20-79 år i en stor studie, der bl.a. type 1-diabetes og type 2-diabetes ble kartlagt (1). Insidensen for selvrapportert diabetes var 3,2 (per 1000 personer) i 1990 og 8,8 i 2008 , men sank så til 7,1 i 2012. Tendensen til synkende insidens i slutten av perioden ble ikke påvist hos svarte eller latinamerikanere. Forekomst av diabetes var lavest hos dem med høyere utdanning og høyest hos overvektige, dvs. dem med kroppsmasseindeks på over 30 .

- Dette er en interessant studie som kan indikere at diabetesepidemien er i ferd med å stoppe opp, men det er det likevel for tidlig å si noe sikkert om, sier Kåre I. Birkeland, som er avdelingsleder ved Avdelingen for endokrinologi, sykelig overvekt og forebyggende medisin, Oslo universitetssykehus og professor ved Universitetet i Oslo. Hans gruppe har nylig publisert en studie basert på tall fra Reseptregisteret, som viser en liknende trend. Antall nye brukere av perorale antidiabetika per år var lavere i 2010 og 2011 enn i perioden 2005-09 (2).

- Styrken i studien fra USA er at man har spurt et stort antall individer om diabetesstatus årlig gjennom mer enn 30 år. En svakhet er at man kun baserer seg på selvrapportert diabetes og at man mangler biomarkører som kan avsløre udiagnostisert diabetes og andre risikofaktorer, sier Birkeland.

\section{Tor Atle Rosness}

Tidsskriftet

\section{Litteratur}

1. Geiss LS, Wang J, Cheng YJ et al. Prevalence and incidence trends for diagnosed diabetes among adults aged 20 to 79 years, United States, 1980-2012 JAMA 2014; 312: 1218-26.

2. Strøm H Selmer R, Birkeland Kl et al. No increase in new users of blood glucose-lowering drugs in Norway 2006-2011: a nationwide prescription database study. BMC Public Health 2014; 14: 520

\section{Sunn livsstil gir mindre svangerskapsdiabetes}

\section{Et sunt levesett før svangerskapet gir betydelig lavere risiko for svanger- skapsdiabetes. Dette gjelder både kvinner med normal vekt og dem som er overvektige.}

Kvinnens livsstil før graviditet kan ha betydning for risiko for å utvikle svangerskapsdiabetes og også for døtrenes risiko for å få sykdommen. I en prospektiv kohortstudie har amerikanske forskere studert effekten av gunstige livsstilsfaktorer som hver for seg er assosiert med lavere risiko for svangerskapsdiabetes (1).

Studien omfattet over 20000 enkeltfødsler hos nesten 14500 kvinner uten kronisk sykdom. Førstegangs forekomst av svangerskapsdiabetes ble rapportert i 823 graviditeter. Kombinasjonen av det å være ikke-røyker, drive moderat til intensiv fysisk aktivitet og ha sunt kosthold var assosiert med $41 \%$ lavere risiko for svangerskapsdiabetes sammenliknet med alle andre graviditeter. Tar man $\mathrm{i}$ analysen i tillegg med kroppsmasseindeks $<25$ før graviditet, var risikoen $52 \%$ lavere. De som oppfylte kriteriene for sunn livsstil, hadde $83 \%$ lavere risiko enn kvinner med usunn livsstil.
- Det er viktig å få gode studier om svangerskapsdiabetes som bidrar til å forklare årsaken til sykdommen, sier postdoktor Kjersti Mørkrid ved Folkehelseinstituttet. - Selv om det er mange feilkilder i selvrapporterte data, viser denne interessante studien at unge kvinners livsstil er viktig for å forebygge svangerskapsdiabetes. Kroppsmasseindeks er en sentral risikofaktor, men studien får også frem at fysisk aktivitet og sunt kosthold er viktig uavhengig av kroppsmasseindeks. Det er et viktig budskap til unge kvinner at deres livsstil kan påvirke risiko for overvekt og diabetes i fremtidige generasjoner, sier Mørkrid.

Trine B. Haugen

Tidsskriftet

\section{Litteratur}

1. Zhang C, Tobias DK, Chavarro JE et al. Adherence to healthy lifestyle and risk of gestational diabetes mellitus: prospective cohort study. BMJ 2014; 349: g5450.

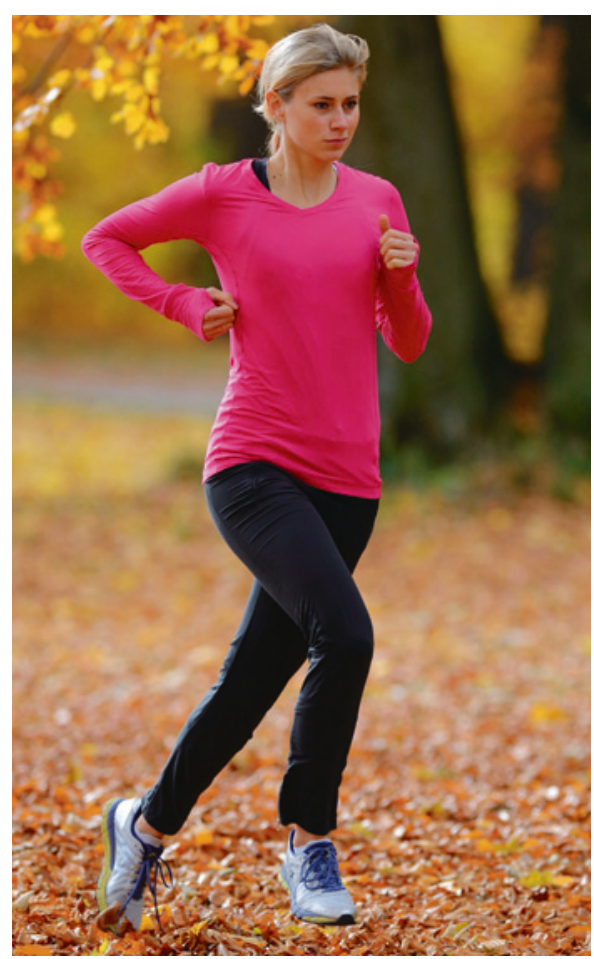

Illustrasjonsfoto: Michael Rauschendorfer/NTB scanpix 